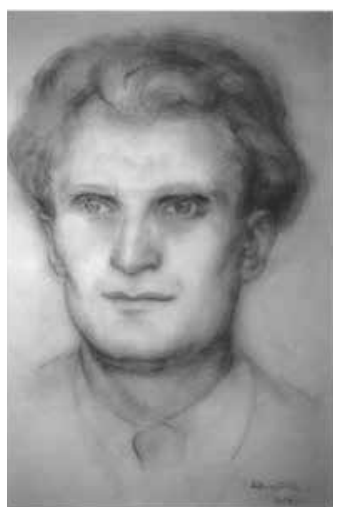

\title{
JUOZAS BALČIKONIS
}

\section{DAILININKAS \\ JUOZAS BALČIKONIS}

Lietuvos tekstilès mokyklos patriarchas JUOZAS BALČIKONIS (1924-2010) gimė Giedraitinèje, Ramygalos vlsč., Panevėžio r., kur baigè Ramygalos vidurinę mokyklą. Studijavo Kauno taikomosios ir dekoratyvinès dailès institute. Čia jam didžiulę įtaką padare L. Truikys. Studijuodamas aistringai domėjosi lietuvių liaudies menu ir Rytų daile, kolekcionavo jų kūrinius. Nuo 1949 m. pradèjo dèstyti savo alma mater Kaune, o 1951-1989 m. buvo Lietuvos dailès instituto Tekstilès katedros vedẻjas, nuo 1972 m. - profesorius.

Knygų Liaudies menas. Audiniai (I d. 1957; II d. 1962), Audinių raštai (1961), Juostos (1969), Tautiniai drabužiai (1970) ir kt. autorius.

Nuo 1947 m. dalyvavo daugelyje parodų Lietuvoje ir įvairiose Europos, Azijos, Amerikos ir Afrikos šalyse. Su J. Balčikonio vardu susiję beveik visi reikšmingiausi XX a. lietuvių tekstilės meno raidos įvykiai dailininkas pedagogine, organizacine ir kūrybine veikla daug prisidèjo prie lietuvių tautinės tekstilès mokyklos formavimo. Pagrindinès jo kūrybinès veiklos sritys - gobelenai, rištiniai kilimai, batikos technika sukurti kūriniai, dekoratyviniai audiniai, mišrios technikos kompozicijos, tautiniai kostiumai. Parengè tautinių drabužių eskizu 1955 ir 1960 m. Dainų švenčių dalyviams.

J. Balčikonis yra apdovanotas Valstybinės premija, Lietuvos kariuomenės kūrèjų savanorių medaliu (2000) ir LDK Gedimino ordino Karininko kryžiumi (2001).

\section{Artist Juozas Balčikonis}

JUOZAS BALČIKONIS (1924-2010), one of the patriarchs of Lithuanian Textile School, was born in Giedraitinė, Ramygala district, Panevežys region. He graduated from Ramygala Secondary School. During his study at Kaunas Applied and Decorative Arts Institute, he was greatly influenced by L. Truikis. Balčikonis was passionately interested in the Lithuanian folk art as well as in Oriental art and collected their samples. Since 1949, he was a teacher in Kaunas Applied and Decorative Arts Institute. From 1951 till 1989, he

| Vytautas KAIRIŪKŠTIS. Juozo Balčikonio portretas. 1956. Popierius, anglis. 36,5 × 31. LDM

RAKTAŽODŽIAI: Juozas Balčikonis, tekstilè.

KEY WORDS: Juozas Balčikonis, textile. 
headed the Textile Department at the Lithuanian Art Institute. Balčikonis authored "Folk art. Fabrics" (I dated 1957, II dated 1962), "Tissue Patterns" (1961), "Tape" (1969), "National Clothing” (1970) and other books. Since 1947, he participated in many exhibitions in Lithuania and in various countries of Europe, Asia, America, and Africa. Almost all the most significant pedagogical, organizational and creative events in the 20th century Lithuanian textile art were related with him. He contributed a lot to formation and development of the Lithuanian National Textile School. The main areas of his creative activity were tapestries, woolen carpets, batik technique pieces, decorative fabrics, mixed technical compositions, national costumes. In 1955 and 1960, he designed folk costumes for the "Song Festival“. Balčikonis received the State Award and was decorated by the Medal of the Lithuanian Army Creator and Volunteer (2000) and the Order of Grand Duke Gediminas (2001).

Prof. dr. Antanas Andrijauskas Lietuvos kultūros tyrimų institutas, Lietuva Lithuanian Culture Research Institute, Lithuania

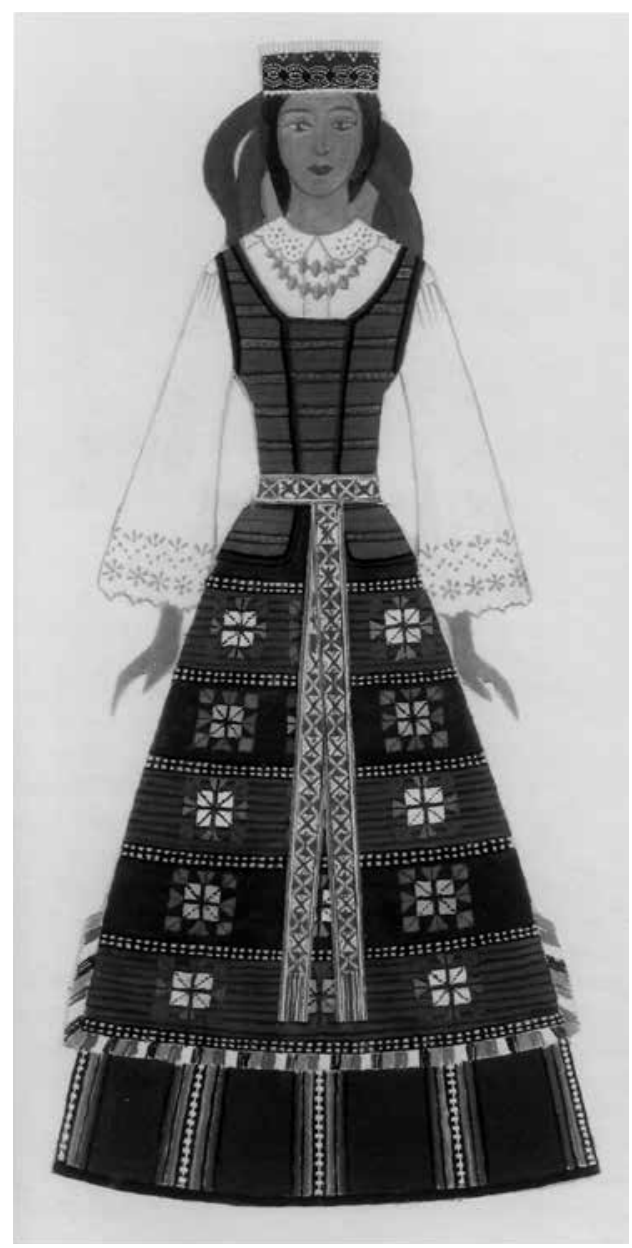

Juozas BALČIKONIS. Suvalkietės kanklininkès kostiumo Lietuvos dailès muziejaus kankliu ansamblio projektas. 1987

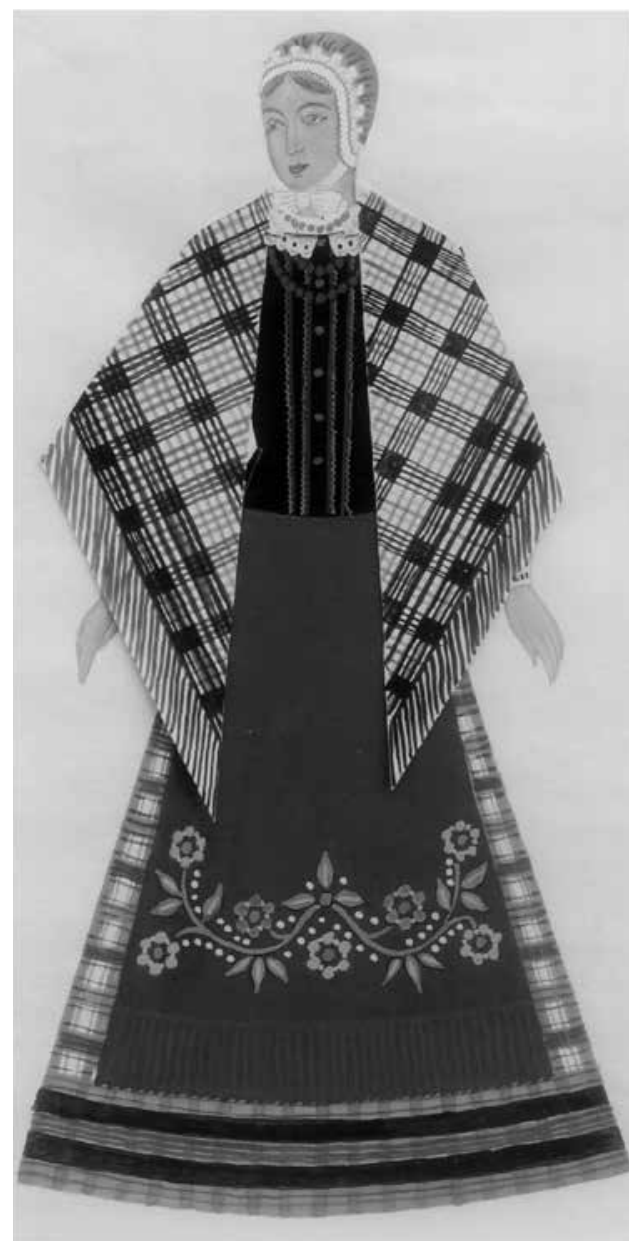

Juozas BALČIKONIS. Dzūkès šokejos kostiumo valstybiniam dainy ir šokių ansambliui "Lietuva" projektas. 1988 


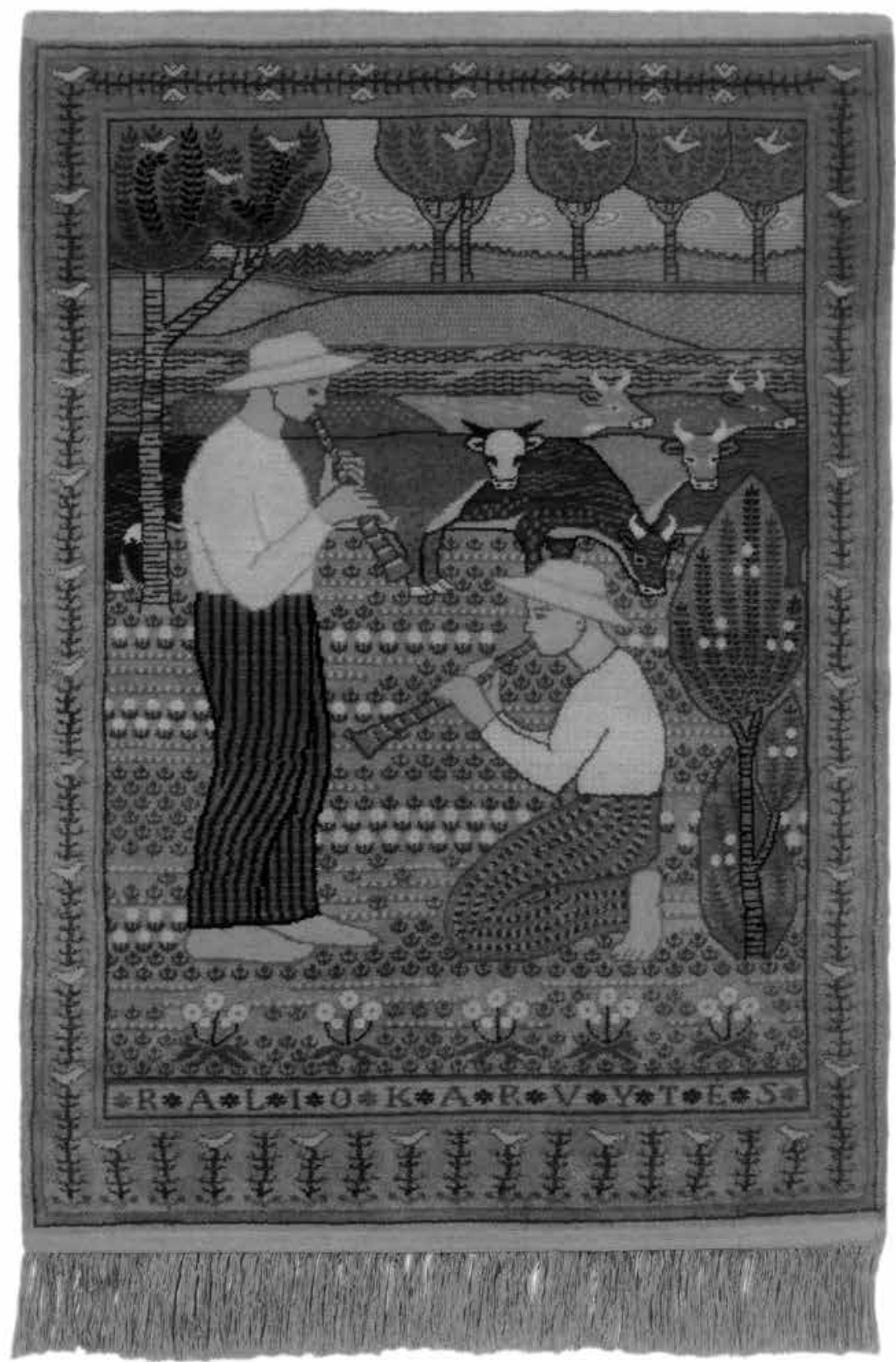

Juozas BALČIKONIS. Ralio karvytès. 1960. Rišimo technika. Vilna. $210 \times 130$. LDM 


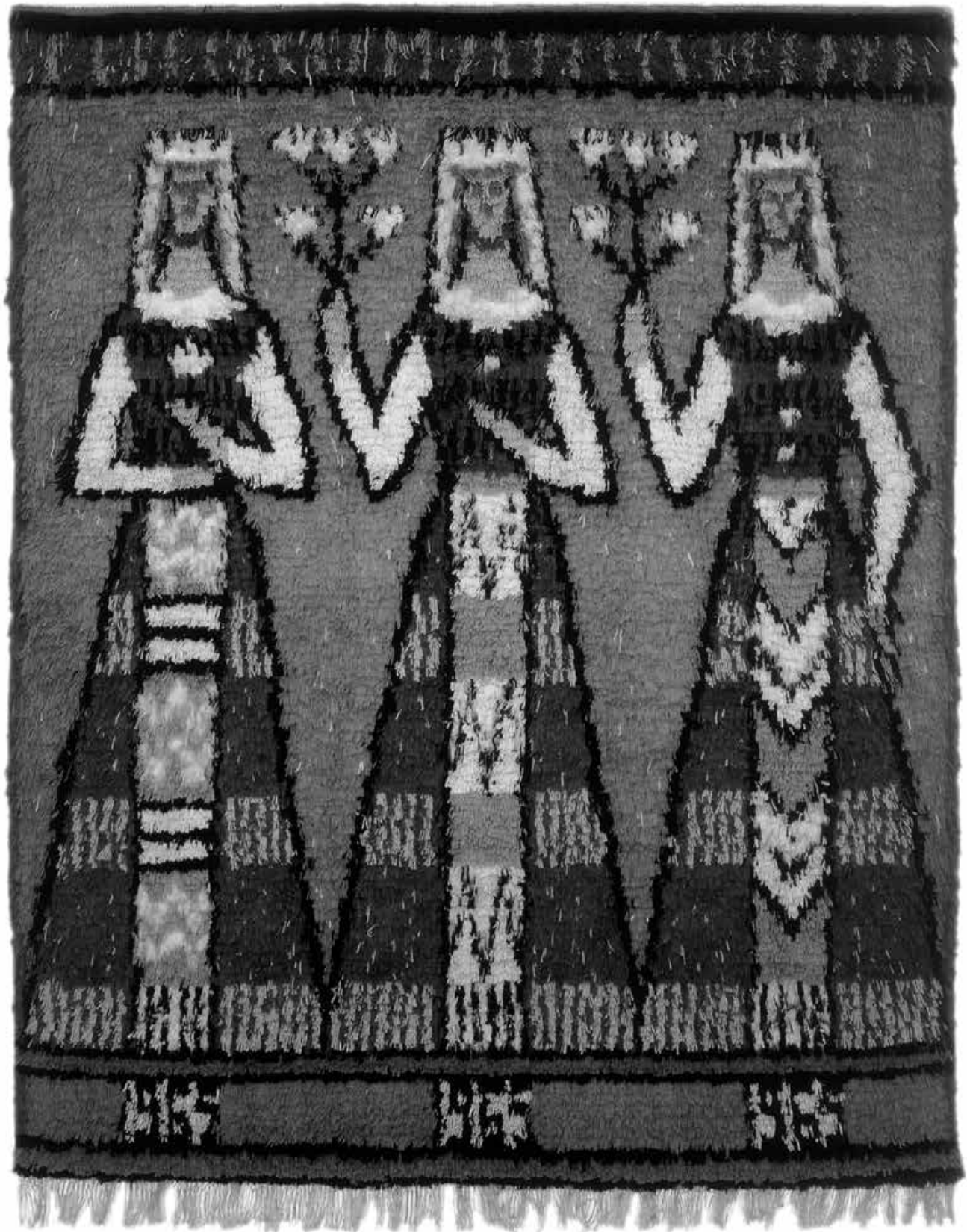

Juozas BALČIKONIS. Žiedai Tévynei. 1965. Riju technika. Vilna. $215 \times 170$. LDM 


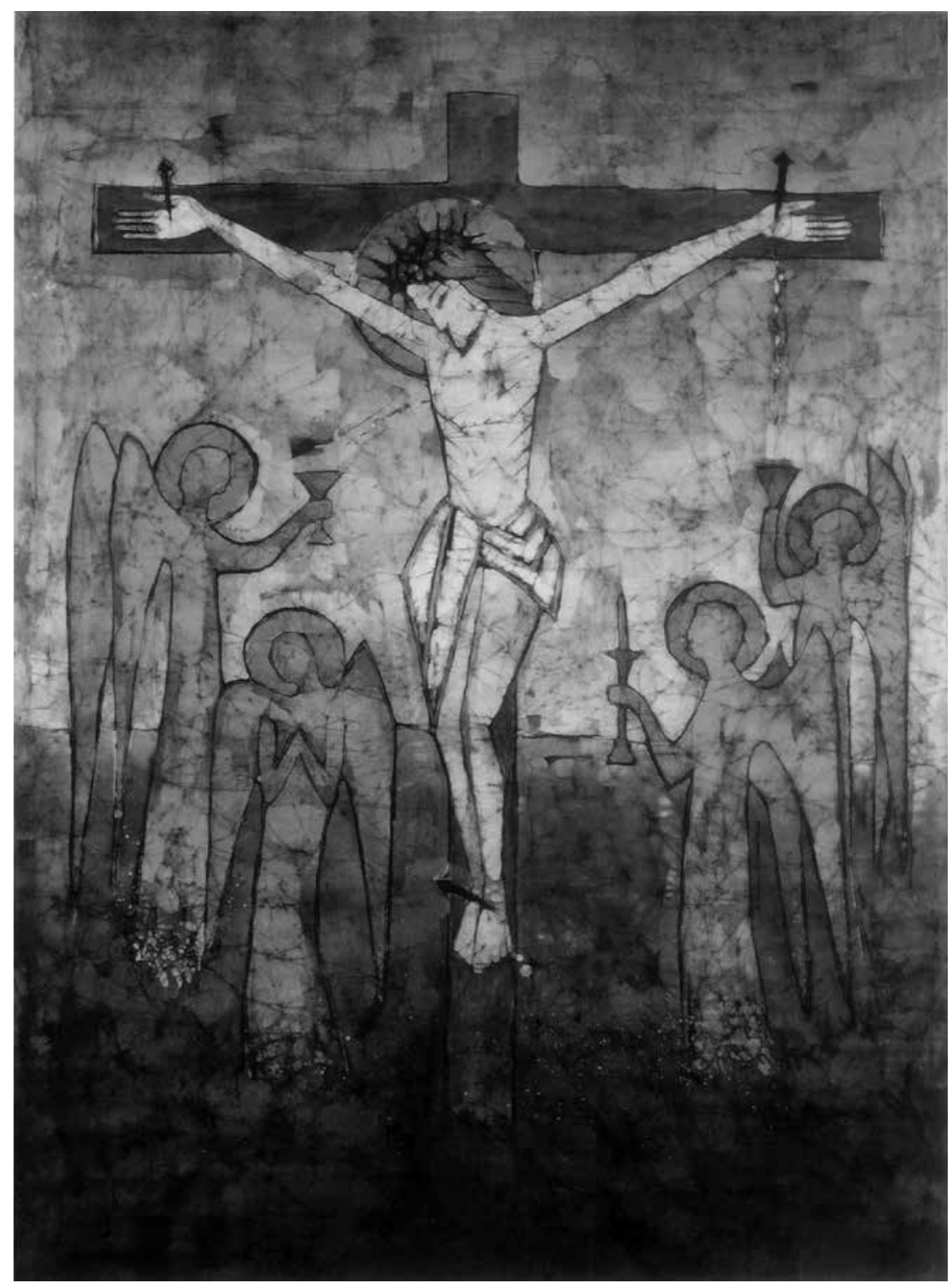

Juozas BALČIKONIS. Nukryžiuotasis I. 1990. Batikos technika. Medvilnė. $202 \times 145$ 


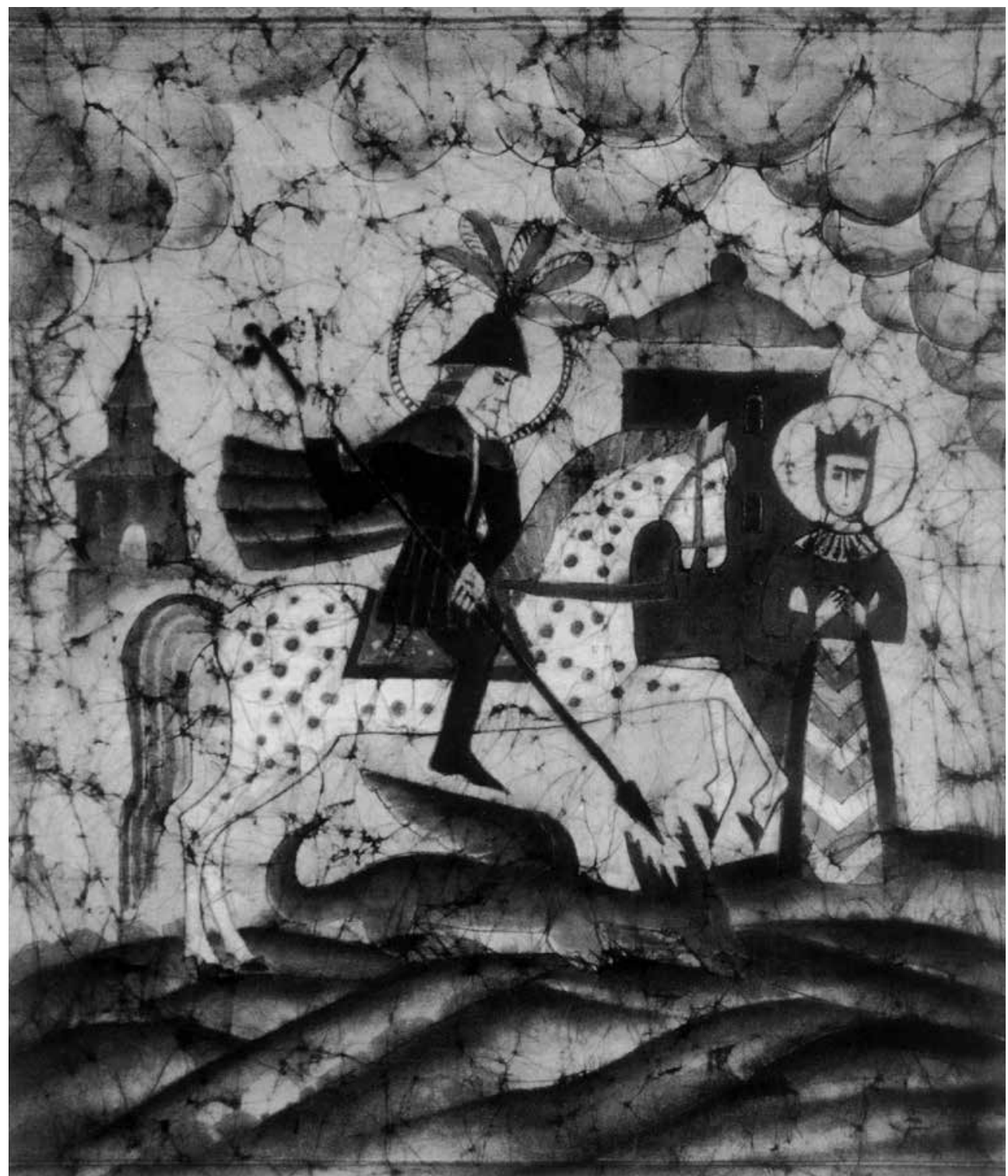

Juozas BALČIKONIS. Šv. Jurgis. 1993. Batikos technika. Medvilnè. $92 \times 70$ 


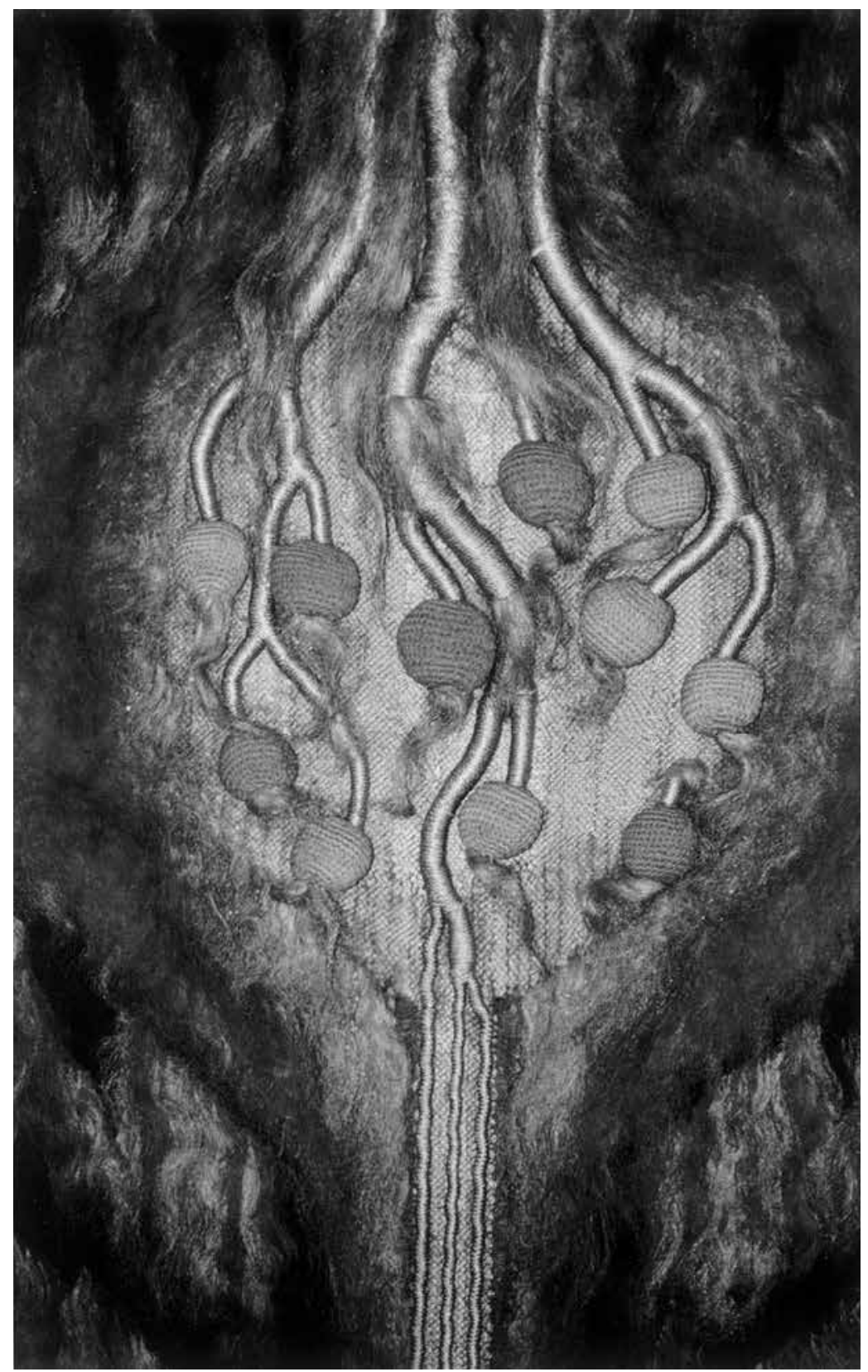

Juozas BALČIKONIS. Ruduo. Iš ciklo "Metu laikai". 1977. Mišrioji technika. Vilna, džiutas, sizalis. $330 \times 220$. LDM. Fragmentas 


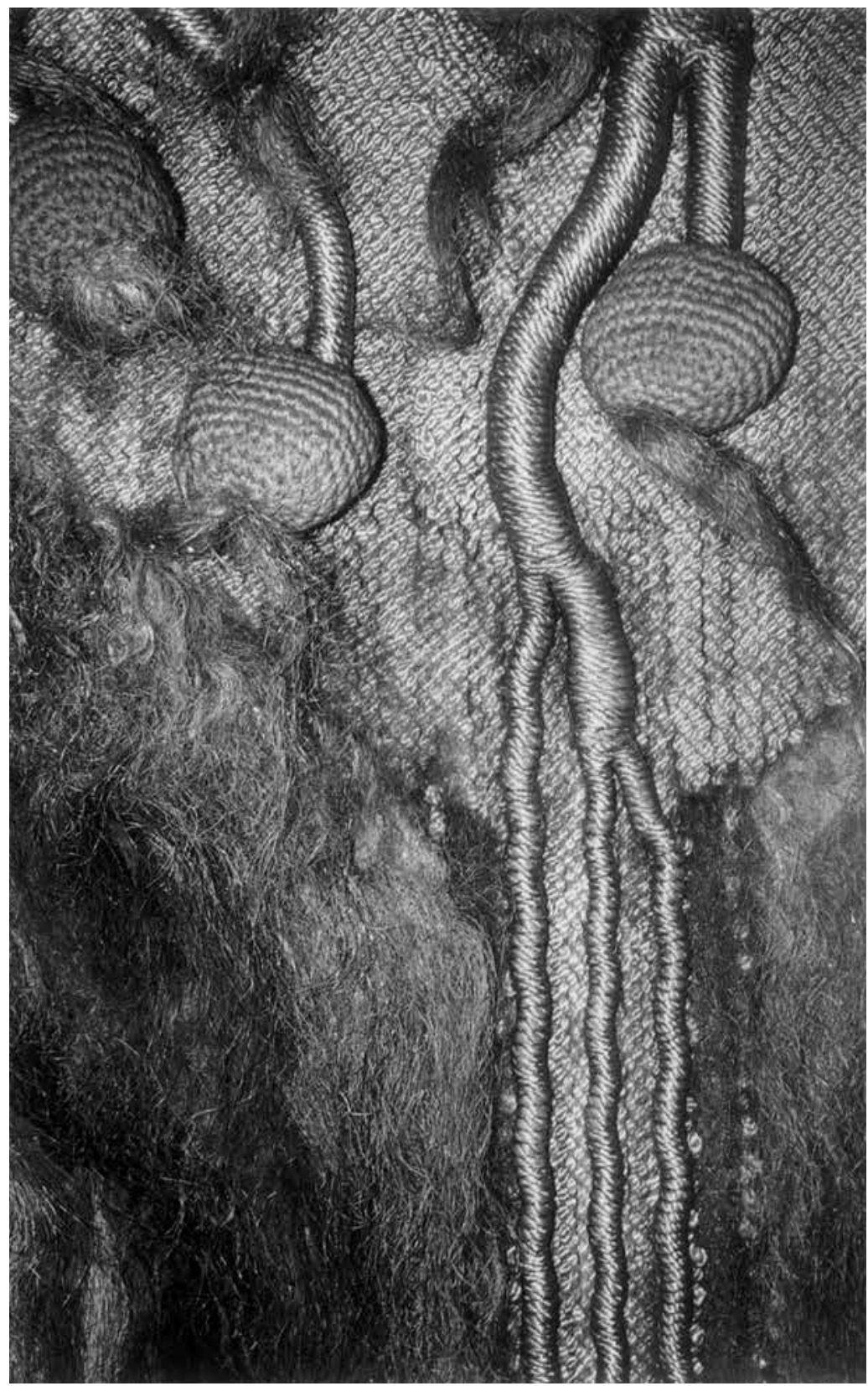

Juozas BALČIKONIS. Ruduo. Iš ciklo "Metų laikai”. 1977. Mišrioji technika. Vilna, džiutas, sizalis. $330 \times 220$. LDM. Fragmentas 